\title{
1 Cities by and for the People
}

\author{
Yves Cabannes, Mike Douglass, Rita Padawangi
}

\begin{abstract}
'Cities by and for the people' indicates the active role of urban citizens in constructing spaces in the cities. The collection of narratives in this book brings together research from ten cities in Asia to contribute to re-theorizing the city from the perspective of ordinary people who face moments of crisis, contestation, and cooperation to create alternative spaces from those produced under prevailing urban processes. The chapters in this book accent the intertwining of 'human flourishing' with the exercise of human agency through daily practices in the production of urban space, placing people in the centre as agents of city-making with discontents about their current conditions and desires for a better life. The cases brought together in this volume each tell us what people strive for when they mobilize with others to produce urban spaces. One of the important theoretical lessons is that the appropriation of space for de-commodified, alternative visions of urban life is not permanent. Sharing space is an opportunity to build collective actions and initiate discussions on the collaborative management of the place. In practice, these processes may be far from ideal and may be subjected to local forms of power imbalances. Although they are spaces of continuous struggles and are embedded with specific limitations that include local hierarchies and contradictions, these convivial spaces are places that actively demonstrate the possible alternative ways to produce urban spaces.
\end{abstract}

Keywords: human flourishing, human agency, alternative spaces, place-making

Cabannes, Yves, Douglass, Michael and Padawangi, Rita, Cities in Asia by and for the People. Amsterdam: Amsterdam University Press, 2018 DOI: $10.5117 / 9789462985223 / \mathrm{CHO1}$ 
The sources of urban discontents in Asia today are manifold and are increasing. As Asia continues its accelerated urban transition, its cities are found to be becoming more unequal in both participation in public decision-making and the distribution of material and social benefits (Padawangi, Marolt, and Douglass 2014). Convivial spaces for the 'pure enjoyment of social life' (Peattie 1998) are being appropriated by commercial interests on a massive scale (Chang and Huang 2008; Daniere and Douglass 2008). In addition, Asia's cities are now adding substantially to environmental pollution and deterioration, including global climate change (UNESCAP 2012). These and many other issues provide the contexts and motivations for people to claim the right to make and change the city—-to assert through their actions that cities are by and for the people (Lefebvre 1991; Harvey 2003). This book covers a wide array of social mobilizations, which together show that expressions of human agency in cities in Asia are not solely directed toward economic or material benefits, but they instead reach toward human flourishing much more broadly through ways of living that validate personal worth through shared cultural and social relations and meanings as use-values.

The issues highlighted in this book arise from corporate-driven, statesupported transformations of cities in a region that is now undergoing the fastest and most comprehensive urban transition in world history. In this context, Cities by and for the People is an exploration of a wide spectrum of counter-hegemonic mobilizations demonstrating that another urban future-one that supports human flourishing for all—is possible. The specific foci of these efforts are manifold. While some succeed, others do not; yet despite failures, the numbers grow. Taking a longer-term view, the stories in this book reveal that human agency, collectively mobilized, can effect changes in the everyday life of cities at small as well as large scales of the urban condition.

The collection of narratives contained in the present book, Cities by and for the People, brings together research from ten cities in Asia to contribute to re-theorizing the city from the perspective of ordinary people facing moments of crisis, contestation, and cooperative quests to create alternative spaces to those produced under prevailing urban processes. As one volume in a three-volume series on Asia's urbanization processes and cities that adopts the guiding concept of 'human flourishing', the chapters in this book accent the intertwining of this concept with the exercise of human agency through daily practices in the production of urban space. The intention is 
not to create a romantic or utopian vision of what a city by and for people ought to be. Rather, it is to place people in the centre, as agents of city-making with discontents about current conditions and desires for better lives. The cases brought together in this volume each tell us what people are striving for when mobilizing with others to produce urban spaces.

2

\section{Cities by and for the People}

'Cities by and for the people' indicates the active role of urban citizens in constructing spaces in cities. Critical urban theorists have rightly decried the impact of urban restructuring in response to economic crises and alternative visions of urban life, which has led scholars' attention towards cities for people (Brenner, Marcuse, and Mayer 2012). Although we continue to examine how the right to the city is made manifest, our emphasis on cities 'by', rather than just 'for', people intends to highlight the role of citizens as active agents of urban change rather than as passive victims of global capitalism. This focus on citizens as active agents is meant to fill the gap between critical theory and urban futures that continues to widen in present urban development trajectories, which persist with business as usual. The acknowledgement of the importance of citizens' active roles, how these roles arise, and the ensuing possibilities are key issues to be thoroughly addressed to enable alternative visions to grow and be consistently implemented against the urban development paradigms that have been rebuked by critical urban theorists. Central to the endeavour of proposing cities by and for the people is this question: What are possible alternative spaces in the city, and how do they come together to reflect a city by and for the people?

Since the 1970s, the flow of global assembly work to cities in Asia has altered the peripheral urban landscapes to facilitate large industrial economic zones. This has triggered waves of urbanization in the search of perceived better livelihoods in rapidly growing cities. By the late 1980 s, finance capital and new consumptive lifestyles arrived along with increases in disposable income and people's participation in the global economy. From this point on, the urban core has experienced thorough transformations through the privatization of urban spaces for mega-projects ranging from shopping malls to world business hubs and the world's tallest buildings. Large-scale gated housing estates and private new towns began to occupy agricultural land in peri-urban areas. Cities that had fewer than 1 million residents in 1970 have grown to as much as 30 million within the short space of three decades, 
driven by globalization and the new international division of labour. Along with this growth and change has come new urban lifestyles that widen social differences and disparities as countries become more complexly urban. The attention given by governments and commercial interests to these new lifestyles and global consumption has diverted urban development discourse away from vernacular landscapes and public spaces-no matter how contested they are-as well as from building meaningful urban neighbourhoods and communities.

Together, the following chapters illuminate the paths and struggles of people working hand-in-hand to prevent the appropriation of life spaces, reclaim those they have lost, and create new spaces of hope. Regardless of outcomes in terms of achieving specific objectives, contestations are expressions of agency through self-empowerment in the specific contexts and aspirations of those engaged in them. They evoke the long-held understanding of the city as a theatre of social action (Mumford 1961; Friedmann 1962) that is diverse in identities and aspirations for defining what the city is and should be. From this perspective, the city is always a process and an outcome of social and political mediations.

With the ascendancy of neoliberal ideology from the 1980s onward, the long-standing idea of the city as a social process has been actively displaced by state and corporate interests claiming the city to be first and foremost an ultra-competitive engine of economic growth and maker of wealth-which justifies a constant prioritization of the economy over social, political, and cultural relations (EIU 2012). Ideologically, this discourse comprises a conscious forgetting of the city as an inclusive polis of participatory politics and as spheres of everyday social life (Kirby 2002). By asserting that there is no alternative to the subordination of society to the mechanics of global economic competitiveness, it deflects critical thinking about and attempts to depoliticize the social unevenness of globalization.

Despite increasing corporatization of cities, efforts continue to be made to counter the alienating forces of capitalist urban growth, including resistance, mobilization, and cooperative projects for alternative development pathways. The practices-simultaneously physical and social - through which urban space is produced are observable, and may help in theoretically defining the 'people' who could (and should) build the city. Local initiatives in neighbourhoods and districts, including efforts to manage and govern these areas, are key manifestations of an inclusive city by and for the people. For example, local practices such as community gardening might start at a small scale but can spread 
throughout the city and to other urban areas. Several cities in Asia have begun to practice participatory budgeting, in which district residents are involved in identifying problems that need to be rectified in their localities. In some countries, communities are printing and using their own currency as a way to enhance synergistic economic linkages within them. Other communities are adopting collective tenure as a means to prevent land speculation and gentrification.

In drawing from real world experiences, the case studies in this book also expose the limitations of collective efforts to confront and transform structures of power. Inequalities and uncertainties have grown together with the urban population and its diversity in today's megacities. Cities with annual high rates of economic growth over many decades continue to have widening social divides with a persistence of very low-income employment and inadequate housing ('slums'). These trends reveal that the role of cities as generators of increased prosperity for all and as new forms of egalitarian civilization - as portrayed in Western theories that inequalities will decline at high levels of per capita income or assessments that Asia's 'miracle economies' demonstrate exceptional experiences of growth with equality-has not occurred.

For these reasons, redefining and reiterating the idea of the city in urban theory is critically needed to connect epistemologies with current urban experiences. Redefining the idea of the city fundamentally means revisiting the right of people to be principal agents in constructing urban spaces, both socially and physically. Such a reconceptualization would include, but also go beyond, economic and material aspects of what is summarized as 'development' to include other important elements of human flourishing as defined in the process of social attempts to create alternative cities to those that are appearing today.

In exposing the sources of and responses to discontents, each chapter in this book is a reflection of particular moments in a specific setting. While variations among specific local contexts in Asia are substantial, the problematics arising in Asia have common elements that have changed with global dynamics over the past half-century, both spatially and socially. For example, in an increasingly multi-cultural world in which both international and intra-national migrations are fuelling the growth of cities throughout Asia, an inclusive society cannot limit the idea of 'cities by and for the people' to citizens or legal residents, but will instead be judged by how it creates the city as a cosmopolis that welcomes the stranger (Sandercock 1997; 2003). However, the notion of the 'stranger' in the city is unequal, as one group of strangers may be more welcomed politically and socially than others. 
In Asia today, international and intra-national migrant workers receive incomes well below those of registered residents of the city, are quickly disposable, have exceptionally limited rights to collective consumption and to the city, and are not in line to become either permanent residents or citizens of the city or nation. In these circumstances, the idea of the city and the epistemologies used to understand the urban condition require a greater appreciation of how cities can accommodate and thrive from social, ethnic, and cultural diversity - which appears to be one of the greatest urban challenges of the twenty-first century.

A key point of departure for the re-conceptualization of the city through the lens of 'by and for the people' is understanding that human action is space-forming and space-contingent (Friedmann 1987), and that, as proclaimed by Lefebvre (1991), changing society requires the production of enabling spaces. The research in this collection reveals why and how social efforts toward human flourishing are also efforts to produce spaces that are realized (or not) through both contestations and collaborations, through both resistance and cooperative projects for alternative processes of city making and dwelling.

\section{Theorizing the City by and for the People: Actors and Processes}

Accepting society-space reflexivity as a core element in theorizing the city as a social process invokes a series of further questions. First, who are the people that are to be viewed as the protagonists? Second, what kinds of communities for collective action do they form and how do they form them? Third, at a broader scale, what are the relations between social collectivities and government - the state - and the larger political economy that structures the production of space? Abstracting insights from the intersections of all of these questions allows the last inquiry into the longer-term viability of the momentum from particular episodes of encounters and struggles to appropriate or create alternative spaces.

Each of these questions is addressed in the context of the experiences of the cases assessed in this book through an examination of the innovations, tools, and strategic options that are created or chosen as contestations turn toward collective projects. This book, then, investigates three different lines of inquiry: the actors who create alternative city spaces; the alternative spaces themselves; and the prospects for the longer-term resilience of efforts to create alternative spaces. 


\subsection{Who are 'the people' that mobilize to produce alternative life spaces?}

In the chapters of this book, quite a broad spectrum of those usually considered to be invisible, vulnerable, or excluded from the system are engaged in producing alternative spaces in one form or another: street hawkers and street traders, as exemplified in Ahmedabad and Hong Kong (Oriard, this volume; Yip, this volume); rockers - and not only young ones - in Singapore (Ferzacca, this volume); common people who will become artists in Japan (Koizumi, this volume); kampung (traditional forms of neighbourhoods) builders (Hellman, this volume); fishermen (Susilo and De Meulder, this volume); and urban farmers and low-income housing tenants (Boossabong, this volume; Gerbeaud, this volume). One of our major findings is that there is life below the radar of neo-liberal or developmentalist cities, and that, despite difficulties, people are resisting and struggling for a better 'everyday life' and for living in dignity.

Human agency is an important concept for understanding people's ability to struggle and resist developmentalist paradigms in the various case studies presented in this book. In the psychology literature, the modes of human agency are differentiated into personal, proxy, and collective, which are related but have different purposes. Human agency is essential in the effort to push for political and social change as a collective. 'The conjoint influence of perceived collective political efficacy and trust in the governmental system predicts the form and level of people's political activity' (Bandura 2000, 78): whether it is participatory, such as the case of Seoul's migrants with the mayor (Cho, this volume) and participatory housing and gardening in Bangkok (Gerbeaud, this volume; Boossabong, this volume), or resistance like the Sario fishermen on the Manado coast (Susilo and De Meulder, this volume). Between participation and resistance, the cases of Kampung Pulo in Jakarta (Hellman, this volume) and musicians in Singapore (Ferzacca, this volume) reflect another manifestation of human agency in the form of grassroots initiatives that do not depend on engagement with the government. Intentionality, forethought, self-reactiveness, and selfreflectiveness - the four core properties of human agency — contribute to social circumstances within neighbourhoods; these are only possible when people can both observe and directly experience the effects of their actions in changing their surroundings and making things happen (Bandura 2006). Although individuals and groups are also shaped by social structures, human agency has the potential to impact the social level more broadly by shaping a better and more sustainable future (Battilana 2006; Bandura 2006, 177). 
How do communities gain the collective agency to intervene for better neighbourhood spaces? In urban development, late capitalism has created a socially disempowering economy that has made human agency precarious (Chandler 2013; Jokinen 2016). With precarious agency, everyday life floats without moorings and has to endure disorientation and insecurities (Jokinen 2016). The existing social structures and institutions may give power to some actors and not to others (Battilana 2006, 660); this power is dependent on how the actors' subjectivities are empowering under the conditioning of the social and spatial settings of the city (Häkli and Kallio 2014). Positions (both formal and informal) in neighbourhood organizations affect individuals' willingness and modes of engaging in efforts that are different from the mainstream (Battilana 2006). The papers in this book demonstrate that while neighbourhood- and urban-scale interventions can only take place officially when acknowledged by the government, they may still happen without official approval through self-help and communal support.

The studies selected for this volume cover the actions of a broad spectrum of people, many of whom would be listed under the categories that Iris Young (2004) categorized as oppressed through exploitation, marginalization, powerlessness, cultural imperialism, and violence. In cities in Asia today, many forms of oppression come from powerful actors in urban politics, which result in systematic dispossession by both market forces and state control, quite often through gentrification and eviction (Shin 2015; van Voorst and Padawangi 2015). These oppressions affect financially and politically weaker groups such as street hawkers and street traders, slum dwellers, migrant workers, ethnic minorities, small-scale producers such as fishermen, low-income populations in vernacular neighbourhoods produced by people who live in them, and many others who in turn become the agents of insurgent action for alternative cities. Although they mobilize through self-empowerment, these groups also find allies within the middle and elite classes who champion their causes. These patterns show that life below the radar of smart, neo-liberal, or green cities has its own potential and vitality, and that despite difficulties, people are resisting and struggling for a better everyday life and to live in dignity in the city and beyond.

\subsection{What are 'communities' and how do we understand social 'networks'?}

'Community' can be a vague concept, but the formation of communities is universal and central to social mobilizations for alternative city-making. While the term 'community' can mean collectives of people with common 
interests that are not spatially defined, the subjects of the chapters in this book invariably gather at specific locations, ranging from a construction site or public square to a neighbourhood or even larger-scale urban arena in front of city hall. Some of these communities might be composed of members of specific groups, but as struggles unfold they can become more diverse. They might exist for only the moment in which they reach a shared 'moral high ground', or they might endure through time as named organizations. In all of these communities, networks are formed. In the contemporary world, mobilizations for reform or for changing the city can instantly reach global scales through social media, although such mobilization is unlikely to last very long in most instances. In sum, these case studies show communities and networks to be dynamic processes, with some core elements longer lasting than other. Such dynamics lie at the heart of the question of the durability and sustainability of a city by and for people, which is in essence the continuous contradiction between the spontaneity and agility needed to confront new oppositional configurations and the predictability and continuity needed to maintain organizations.

Although the chapters in this book consistently show hopeful cases to highlight the possibilities of alternative visions of urban life, none of the presented alternatives is ideal. First, the contemporary fragmentation of urban visions among different groups of residents may result in contradictions between the aspirations of different communities and other forms of domination and subordination. The case of street vendors in Ahmedabad (Oriard, this volume) illustrates this complexity, as the street traders exert the right to their existence, but at the same time convert segments of public spaces into their own commercial spaces. Susilo's chapter shows how the Sario fishermen of the city of Manado continued to fight reclamation and re-assert their existence through the construction of the Daseng space, but at the same time another fisher community considered the building of a commercial boulevard on reclaimed land to be a sign of progress.

Second, religious and gender identities can provide different layers to the dynamics of alternative spaces. For example, the chapter by Hellman on kampung (urban village) as a commons describes an interesting alternative form of communal land tenure, although it is not acknowledged by the state and part of it was evicted in August 2015 as we were writing this introductory chapter. At the same time, the community has very clear gender roles and women are not yet fully involved in anti-eviction meetings, although there are no restrictions on women becoming district heads. The area is also infused with factions of several different political parties and the conservative Islamic Defenders Front. 
Third, communities may form networks beyond their immediate neighbours to work with others in different neighbourhoods, districts, cities, or even different countries. Gerbeaud's case of the community-based upgrading of Bang Bua Canal is now one of the models in the region, to which different riverbank communities look for inspiration. Visits by different riverbank communities from various cities in the region were also linked through the Asian Coalition for Housing Rights (ACHR) network. The start of the Bang Bua Canal upgrading was also not a simple task in which everyone in the neighbourhood immediately came to a consensus that they would reduce the size of their houses. It took months of deliberations, discussions, meetings, and the initial implementation for others to follow through.

In spite of the complexities of the many layers of social identities that may make contemporary alternative urban spaces less than ideal, these efforts by urban citizens to collectively and socially construct their spaces are significant movements to counter the overwhelming capitalist economy that lurks in many aspects of urban life, including land tenure and livelihoods. Because they are not ideal, these alternative spaces are realistic and thus able to illustrate the existing possibilities for counter-narratives of the city.

\subsection{Local state and capital and their relationships with communities}

How do we understand the local state (municipal or urban level) in relation to the idea of the city by and for the people? Classic theories that treat civil society as the organised face of society juxtapose it to the state, or, alternatively, to the state and what Friedmann (1992) calls the corporate economy (capital). From these perspectives, a social contract with the state is implicitly or explicitly formed, which gives the state a monopoly over violence through police and regulatory powers that extend into all levels of the city, down to the street corner. In practice, these relationships can become rife with corruption, authoritarian rule, corporate capture, and other forms of governance that have become exceptionally problematic in city-making.

The chapters in this book illustrate different possibilities of relationships among local state, capital, and communities in the social construction of alternative urban spaces. In the case of the urban farming network in Bangkok, Boossabong argues that the collaborative governance approach to acknowledging NGOs, CBOs and laypeople as partners in urban development resulted in state support for the network, which also includes funding provisions for trainings, consultancies and events. In Ahmedabad, the 
city government has legalized street vending, although this by no means eradicated all problems and contradictions. In the case of the kampung in Jakarta [Chapter 2 in this book], on the other hand, the state does not recognize the legal existence of the community. Similar struggles for recognition are experienced by the communities of Pom Mahakan and Bang Bua Canal in Bangkok (Gerbeaud, this volume), and the Sario fishermen (Susilo and De Meulder, this volume).

Following Castells (1998), and in the context of the state's monopoly of means of violence and problematic urban governance, the relationship between civil society and the state takes three possible forms: first, support of the state and its actions; second, contestation of the state through, for example, strikes or protest movements; and, third, going beyond protest to generate alternative projects. The studies in this book highlight all three tendencies. We can see how the great majority of people often do not join insurgencies of any kind, while others do. Occasionally, issues increase in scale until the majority begins to demand change. In other cases, people create their own alternative spaces with or without state support. The cases presented in the following chapters represent all points in this spectrum of civil society-state engagement.

In the cases presented in this collection, the narratives of civil society relationships with capital, or corporations, are more consistent than those with the state. Most of the cases of alternative urban spaces in this book concern communities that are marginalized by state power working in tandem with the interests of private developers that encroach on their land and thus threaten their livelihoods. This is evident in the cases of the Sario fishermen in Manado and the Baguio market [Chapter 11 in this book] that is threatened by potential development of a big supermarket in the area. As previously discussed, the consistency of the discontents reflects the unequal benefits of urban development in the region, which promotes inequality in an era of global consumption.

Other theoretical formulations bring state-civil society relations into a triangular relationship with capital as a third source of power. In Asia from post-World War II independence to the early 1980 s the state played a dominant role in economy and society, giving rise to what became known as the 'developmental state' characterized rapid state-led economic growth under authoritarian rule. Since the 1980 s, two new dynamics have entered the scene. The first was the increasing prominence of neoliberal policy regimes that sought to subordinate state authority to (global) capital through reforms intended to deregulate national economies and fully open them to global flows of trade and investment. This shift has included the severe 
reduction of government welfare programs. The second dynamic was democratization and, at least in some cases, the devolution of power to local levels of government. Together, these two changes set the stage for new possibilities in state-civil society-capital relationships, which simultaneously brought an ever more powerful surge in the corporatization of cities as well as more open expressions of discontent. In this context, the local state can be seen as ambivalently shifting between supporting various civil society movements while also promoting public-private partnerships with corporate enterprises. Civil society, particularly the middle classes, expresses the same ambivalence. As the cases in this book demonstrate, wherever discontents move from contestations to alternative projects, a visible element of middle class support - whether in the form of NGOs or political activists - is found to be involved.

In a few cases, the local state is also a positive actor: for example, in Hong Kong or Bangkok the local state plays a positive and facilitating, though partial and ad hoc, role in the creation of alternative spaces. In some cases, too, the Petite Noblesse d'État or Petty State Nobility identified by Pierre Bourdieu (1998), which is composed of usually low-ranked (or low-paid) civil servants - such as social workers or primary school teachers-who are in direct contact with citizens are shown to be a transformative force in society, beyond the role of the social movements weakened by years of repression and neoliberal policies.

Of particular interest in this collection of studies is the possibility of creating alternative spaces, which remains a largely understudied subject. How are such spaces maintained through resistance, appropriated through long-term occupation, or remade through community projects?

\section{The Production and Appropriation of Alternative Urban Spaces}

In the current era, Asia is experiencing a massive transformation of urban spaces toward global(ized) cities characterized by large-scale corporate mega-projects, chain stores chains and franchises, privatization of public space, and demolition of the vernacular. Alternatives to these changes require the production of space as well. Efforts toward making these spaces ask several key questions. What forms do these alternative spaces take? How are such spaces appropriated? In the context of the geography of capital, where are they most likely to be found? What are the projects and physical, social and institutional content of such alternative spaces? 


\subsection{Strategic Issues to Initiate Actions}

Giving attention to alternative spaces points toward innovations in creating and maintaining such spaces in the wider context of an ever-present capitalist economy that today has taken neoliberal tendencies. Some of these innovations that are already well known include the implementation of a community currency, social enterprises, collective tenure, and (re-)creating the commons. As shown by the case studies from Japan and Hong Kong, the conviviality of cultural and art festivals can also create social solidarity around alternative projects. In other cases, solidarity forms around shared occupational spheres, such as among fishermen in Manado [Chapter 11 in this book]. In cases where the local state is involved, innovations such as participatory budgeting can play a significant role. Self-provisioning and localizing through linking the production and consumption of food within smaller geographical scales than those of global industrial food production has also become an important activity in alternative city-making, which is shown to have positive multiplier effects in generating allied production. The cases of synergistic links between local small-producer food crops and small-scale venders in the city illustrate these connections. Engagement in food production can also have beneficial effects by contributing to the conviviality of social relations and fostering a greater appreciation of human-nature relationships.

The experiences brought together in this book uncover several issues that can be strategically used to promote alternative urban spaces that can potentially build towards cities by and for the people. These issues are typically considered mundane in urban life, but precisely because they are essential parts of everyday life that lack of access to them may trigger collective action to change the situation. These issues are identified as follows:

\section{a. Culture and art}

In his chapter, Koizumi argues that art projects are potential tools to bring diverse people together. Because the process of doing an art project is a process of forming 'new creations together with other people', the site of the project becomes a place of connection that offers opportunities for bridging groups who might not interact otherwise. In this case, art can be a strategy to connect different groups in an advanced industrial society that is rife with individualism. This can be compared with the case of Singapore (Ferzacca, this volume), which argues that music can create a space for gathering to not just enjoy 
the tunes but also to discuss social and political concerns. This appropriation of sonic space to promote critical thinking connects with the politics of popular culture, which theorizes that while popular culture can be a numbing force of escapism and conformity to market forces of production, it also has the potential to be a tool of resistance and social critique.

\section{b. Markets and trades}

Traditional markets are subjected to modernization projects in line with mainstream urban development trajectories, but which are, at the same time, full of innovations meant to sustain traditional supply systems. Milgram (this volume) reminds us that although the organized sellers in the traditional Baguio City Public Market are practicing a politics of resistance towards the recent construction of shopping complexes, they also show internal inequalities. Marinelli's chapter highlights the dwindling association of marketplaces with communities' public spaces as interpretations of modernity as the sanitization of the urban landscape come at the expense of the vibrant public life of urban marketplaces.

\section{c. Food production and distribution}

Although the definition of the 'urban' is often linked to 'non-agricultural' modes of production, the discussion of food production provokes an exploration of variations and alternatives in the age of planetary urbanization, particularly when considering the power of humans as agents of change. The chapter on collective urban farming in Bangkok (Boossabong, this volume) informs us of how food production becomes a strategic issue that draws different groups of people in the city together and to connect collaboratively with the city government. Similarly, the traders in Baguio market base their social relationships with their customers on trust, which creates the sense that they care about the quality of the food that their customers obtain from them. Likewise, Sario fishermen in Manado [Chapter 11 in this book] might seem to be fighting for their land and homes, but in practice the existence of fisheries in Manado is part and parcel of the cultural identity of the Manadonese, for whom fish is a primary feature of their culinary traditions. The growing sense of care for others and for the urban environment, and the creation of natural landscapes that support the production of and access to edible food in the city are potentially strategic for imagining the environment as a commons, on which social collectives can be formed 
to address problems and to maintain and improve conditions through integrating cultural and social-economic practices with environmental concerns.

\section{d. Settlements and housing provision}

Putting a roof over every head is often a contentious issue exacerbated by the domination of the market, which commodifies housing as property. Our use of the term 'settlements' alongside 'housing provision' highlights differences among actors involved in making and living in them. In this light, the action of making places for settlement can be interpreted as a manifestation of human agency; however, such action is still inseparable from the influences of mainstream discourse. Alternative urban settlements are subjected to the land-property regime that affects residents both materially and mentally, through consistent exposure to the aspirational lifestyles brought by Asia's accelerated urban transition. The chapters in this collection mostly look at settlements that are built by the people in the communities for their use rather than commercial exchange value, and who have faced challenges in the form of threats of eviction in rapidly developing cities as well as bearing the brunt of region-wide environmental degradation. The case of Kampung Pulo (Hellman, this volume) is an example of settlements threatened by both evictions and severe pollution as well as flooding as the population density of the settlements has also increased because of the rapid, spatially concentrated urban development of the capital city.

Housing provision - and eviction - involves direct action by the state, either local or national. Typically lacking the capacity to control or deliver sufficient housing in pace with the rate of urban expansion, government provisions of public or social housing nonetheless remains limited in most countries in Asia. As a result, urban slum populations continue to grow even where national economic growth rates are high. In being mostly produced by dwellers through mutual assistance, lower-income neighbourhoods are experiencing the contradictions of self-help housing being under siege by commercial interests that are leading the production of urban space. As such they have become strategic issues in challenging the mainstream development trajectory of trickle-down economics through filtering of housing from rich to the poor. Pom Mahakan and Bang Bua Canal (Gerbeaud, this volume) are contrasting examples of strategies and results of social movements aimed at maintaining local settlements in the city. 


\subsection{Appropriation and place-making}

What are the possible forms that urban projects by and for the people can take, and how do these urban projects reflect the city as both idea and reality? This question entails an inquiry into the people's roles in place-making practices, the historical-cultural-political and social contexts of alternative development, and the process of obtaining spaces for alternative development. The forms of urban projects by and for the people are inseparable from their functional aspect of fulfilling daily needs and the processes by which they fulfil those needs. Settlements, marketplaces, and production spaces, which are generally subjected to a capitalist development paradigm that reduces these spaces into quantified, abstract values, are strategic entries into the social construction of urban landscapes by and for the people as the civil society act together to survive.

Through their respective cases studies in Jakarta and Bangkok, Hellman and Gerbeaud demonstrate how urban scholars' dominant discourse of understanding settlement improvements in terms of land tenure security is not corroborated by the data. Hellman considers the possibility of seeing the kampung settlement as a 'commoning' process through which self-built neighbourhoods are both collective and non-commodified, partly because their precarious existence has been sustained long enough to establish non-material relationships among the residents. In Bangkok, Gerbeaud has found that heritage preservation and environmental improvement inspire residents to become engaged with civil society, particularly in spontaneous settlements like poor neighbourhoods under threat of redevelopment.

Although most of these case studies feature place-making efforts by the urban poor, to think that cities by and for the people are only relevant for the poor is misleading. Rather than mere tools of survival, alternative urban projects are actions and strategies meant to construct a meaningful urban life. While the empirical cases presented in this volume largely feature the efforts of marginalised groups in urban landscapes, including the poor, because they are disadvantaged in the mainstream urban development trajectory, and thus have the imperative to push for alternative actions, the meaningfulness of place-making is not limited to poor and marginalised groups. This is demonstrated in the chapter on art projects in Japan (Koizumi, this volume), in which middle-class citizens, artists, and concerned citizens from any other group can join hands through the catalyst of art projects. Again, the acknowledgement of street vending by the city of Ahmedabad 
(Oriard, this volume) suggests that city governments can play a supporting role in facilitating the making of cities by and for the people through legal frameworks that are relevant to grounded realities, rather than tools of power used to control space as a commodity.

5

\section{The geography of alternative spaces: Where do alternatives take place? What are the places of resistance and affirmative actions?}

Another important question addressed in this volume is how and where alternative spaces are to be found and (re-)vitalized. The answers are complex, but they also show common patterns. First, as with the formation of organic settlements, they often arise on public land under traditional land-use regimes, or where private-sector control is not in place. Thus some of the contestations detailed in these chapters take place in public parks, plazas, sidewalks, and streets. This raises difficult questions about who should have access to these spaces for what kinds of activities. Another possibility is the revalorization of areas that capital has abandoned, such as old industrial areas, docklands, or even severely environmentally degraded areas. Such places have often become well known as the 'Bohemian' art and music scenes in many cities throughout the world, including in Asia. Similarly, many lower-income neighbourhoods that are undervalued by the market can become sites of alternative development. However, all of these spaces are subject to gentrification, commercialization, and shifts from residential to commercial districts as their very success attracts new rounds of investment. In these instances, the local state becomes a major source of either helping to prevent such colonization or, on the other hand, siding with commercial interests to create cultural economies for economic growth. In Marinelli's terms: “The City's [Hong Kong] "sterilized" regime cleaned off street trade and at the same time killed street performance that often associated with street trades' (this volume).

In their diversity, the various experiences recorded here echo Lefebvre's (1968) writings on the right to the city, which consists of the collective appropriation and use of space rather than individual ownership per se. In that sense, Lefebvre's conception is quite different from, if not opposed to, the commodified, neo-liberal city. In this book, the authors further apply Lefebvre's Right to the City by focussing on the delineation of a city of the people by giving an extraordinary account of streets, markets, housing tenements, central marketplaces, kampung, and the like. While Lefebvre's 
perspective is often critiqued as lacking consideration of scales much below 'the city', the chapters in this book show precisely that the Right to the City is built on limited and specific spaces, thereby echoing Manuel Castells' (1996) theory of spaces of place.

The experience shed light on the process of 'commoning' in David Harvey's sense, or of building common goods, either physically — such as building settlements in a kampung in Jakarta—or sonically—such as music jam sessions in a guitar shop in the basement of a mall in Singapore. The experience in both cases is transformative for the participants, encouraging them to transform their built environment and their everyday lives. This echoes De Certeau's (1984) conception of the practice of everyday life as re-appropriating spaces as one's own. Throughout the examples in this collection, the practices of 'communing' lead to the identification of spatial characteristics that provide a sense of personal efficacy to the people. This is evident in the case of street vendors in Oriard's chapter on Ahmedabad and in Hellman's interpretation of the commons in kampungs. Spaces that are welcoming and open to different groups of people in the city continue to be subjected to appropriations and re-appropriations that may not be consensual, since each group has its own interests. However, it is in the existence of the possibility of appropriations and re-appropriations that human agency can be spatially manifested in the city; this, in turn, is an essential precursor to politically, culturally, socially, and physically constructing cities by and for the people.

How do public spaces enable people to continuously recalibrate their skills to build social relationships and social capital? This is easily observable in the case of urban markets, such as in Baguio or Hong Kong. As previously mentioned, the traders in the market of Baguio [Chapter 8 in this book] build social relationships in conjunction with economic practices in support of their livelihoods. Marinelli's chapter elaborated how Hong Kong street markets are public spaces where social relations are formed. Koizumi's chapter on art projects examines the role of the arts in public spaces as a way to bring people together in the midst of rising individualism. And the importance of public space is also seen in the case of the Sario fishermen in Manado [Chapter 11 in this book], in which the shared space of the Daseng becomes a physical manifestation of resistance against the corporate-driven reclamation of the coast.

One of the theoretical lessons of our analysis of the quest for appropriation of spaces for a better life rather than for more property or more money is that this appropriation is not permanent. It can range from a couple of hours each day, such as street vendors' stalls, to occasional uses during the week or the month, such in art projects and the music jams in Singapore. This 
opens the opportunity for multiple uses of the same space, be it a street, park, or square. At the same time, shared arrangements among the publics of the city emphasize the importance of collective action and decisions to 'manage' this space through time.

An important point to be made here is that solutions to these problems only work if they are collectively organized, rather than individually resisted or attempted. These struggles also highlight the difference between the city as a space of flows and as an outcome of the place-making of the people who reside or work in them. Different property regimes are also at play; from a collective action perspective, many of the tools for alternative spaces revolve around the attempt to create or recreate the commons, i.e., common property regimes. This is highlighted by Hellman's research on Jakarta, which proposes the kampung as a commons, rather than a property regime: it is much more a space of collective consumption. This treatment of land is the outcome of the interconnections among everyday life needs, including public services and public goods; concerns over public safety; and collective identities with the kampung.

What are these alternative spaces used for? In a few cases they are 'venues for expression, and social and political deliberation', as in the Umbrella Movement in Hong Kong (Ming, this volume). Public space may be a landscape of conflicts and resistance, but this is part and parcel of the preservation of functions that matter for people, such as art and cultural expression, trade or agriculture, and conviviality.

From the cases in this book, what is clear is that collaborative actions to construct alternative visions of urban life have ideological resources framing their strategies, intentions, and actions. Koizumi's chapter on the use of art projects in bringing people together has cultural resonance with the machizukuri ('community development') after the collapse of Japan's bubble economy in the early 1990s. The art projects are re-interpretations of the machizukuri, which has also been associated with the construction of public spaces and buildings. Ferzacca's chapter demonstrates the ideological identities of the groups who utilize music as shared spaces to exchange life stories. Conviviality through music uses the space to share social concerns about Singapore as a city-state and to make these conversations meaningful and pleasurable. In Bangkok, where city dwellers consume considerable amounts of vegetables that are usually transported from more than $100 \mathrm{~km}$ away, collaborative urban farming is another expression of the ability to intervene in the soil, in this case to produce good food to be shared (Gerbeaud, this volume). All of these cases show that the alternative spaces that are necessary to make cities by and for the people are ideologically 
rooted in the society. These spaces emerge through the initiative of the existing members of the society, often with networks or linkages beyond the immediate neighbourhood.

\section{$6 \quad$ Policy implications for the sustainability and scaling-up of alternatives}

\subsection{Sustaining alternative spaces in the longer term}

By their very position as alternatives to powerful prevailing modes of citymaking, alternative spaces are likely to continually face the possibility of being eliminated through a variety of well-known processes, including gentrification, government land confiscation for urban revival or renovation, the commercialization of residential areas, and the invocation of land-use regulations, to name a few. In the face of these always imminent threats, how can those who produce alternative spaces find ways to sustain them in the longer term?

Evidence from the studies presented here and from the wider literature suggest three important dimensions of longer-term sustainability of cities by and for people. One is creating virtuous chains of projects in which the success of one contributes to the solidarity and sense of purpose that can in turn generate other projects one after another. Boossabong's chapter demonstrates the possibility of the city-wide spread of urban farming in Bangkok, which started from small-scale individual and collective efforts. A second dimension involves creating the legal and institutional development infrastructure to go beyond a single leader or group of activists by laying foundations in law and governance. Examples include success in the progressive change of eviction laws, the creation of legal bases for collective tenure, and the implementation of institutional arrangements for participatory budgeting. The third is communities engaging with communities through associations that, in raising the scale of collaborative support, increase the voice of civil society in the public sphere.

The expansion of projects along these three dimensions faces many difficulties. The diversity of social identities within and among communities can result in animosities rather than cooperative engagements. Some of the chapters, such as those on street traders in Hong Kong (Marinelli, this volume) and Ahmedabad (Oriard, this volume), show internal community tensions between groups with different interests. Sustainability very much depends on the capacity of a given community to solve these disagreements 
internally. This is similar to the conclusion of URBACT, a cooperation program in Europe that promotes networking and the sharing of experiences and best practices in various urban challenges such as governance, environment, inclusion, and the economy, on conflicts of interest and uses between different groups in the same community. On the other hand, two chapters (Koizumi, Ferzacca, this volume) show how festivals, art projects, and music can assist in bridging social differences, increasing the likelihood of different groups coming together to craft common objectives and work together to achieve them.

Sustaining alternative spaces indicates the resilience of those involved in making spaces and places. Milgram's chapter on the fresh food market in Baguio City is a case in point, in which she discusses the traders' resilience and ability to sustain the process. She concludes that resilience was neither related to 'heroic confrontations with the authorities' nor to collaborative strategies. 'Rather, marketers' everyday politics of resistance to fashion gray spaces of practice materialize a "quiet encroachment" of the "ordinary" through familiarization of the fissures in the working of city government power (Bayat 2004, 81)' (Milgram, this volume). This 'quiet encroachment of the ordinary' is the key to spatial appropriations when constructing alternative urban landscapes, through which the people who are involved become active agents of change in the city through incremental, but relatively consistent, interventions in urban spaces made possible through their daily routines and practical knowledge about how the city functions on both the ground and the policy level.

\subsection{Multiplication of spaces by and for the people}

Most of the experiences recounted here involve a city by the people created through insurgent actions, resistance, and affirmative actions of all kinds. Very few are disseminated at the city level or at higher spatial or political scales. Most of the narratives give an account of alternative place-making at quite a limited scale in relation to the city as a whole, such as a market and its surroundings or a low-income neighbourhood. Limited evidence was gathered on the impact or expansion of such alternative experiences on the city as a whole, whether through getting bigger or multiplying throughout the city. This being said, some of the chapters do shed light on how limited locales by and for the people do connect with the city as a whole. This is the case of Bardha Market (Oriard, this volume) that connects socially and economically with areas far beyond the heritage city where it is located; the same holds true in Ferzacca's chapter on 'jumping spatio-sonic scales 
in Singapore', which shows how various extremely small locales such as a shop or basement are able to gather fans and musicians from the City-State as a whole. Again, Yip's chapter relating the struggle to create alternative urban spaces by a theatre group in Hong Kong illustrates an experience that expanded or sprouted derivations beyond its original boundaries to avoid direct conflict in a repressive situation: "The theatre group eventually decided to withdraw from Sai Yeung Choi Street South and launch new initiatives of diversifying their performance in other areas and new venue of street performance. For instance, "Theatre Everywhere" is a "guerrillas type performance" in open spaces or other busy areas'. Some of the narratives indicate the following mechanisms through which alternative actions can expand far beyond their original limits:

\section{a. Collaborative modes of urban governance}

In his analysis of collaborative urban farming networks in Bangkok in this volume, Piyapong Boossabong argues that 'collaborative modes of governance' were crucial to expanding the City Farm Program beyond its original location. He indicated that local governments recognized NGOs, CBOs, laypeople, and their social networks and development partners. The results of these new forms of collaborative governance included - and this seems quite essential—formulating visions, missions, and strategies that ended up expanding the City Farm Program, and was not limited to supporting grassroots initiatives for alternative development.

\section{b. Removing 'unfreedoms' and bureaucratic hurdles}

Each of these studies demonstrate the numerous difficulties and official hurdles faced by groups engaged in alternative action, including requirements for licensing, harassment, bribes, and the acquisition of health certificates. These barriers come from each city's existing planning rules and regulations, political forces, or private economic interests. A central argument that emerges from these case studies is that the local state can contribute greatly by removing 'unfreedoms' and bureaucratic hurdles, thereby facilitating the upscaling and dissemination of alternative experiences in the city and allowing human flourishing to expand. In the light of Nobel Laureate works, Development as Freedom by Amartya Sen (1999) and Jane Samuel (2005) complements upon Citizens as Agents of Change in Urban Development, to remove unfreedoms, one crucial difference between our case studies and Sen's argument is the importance of collective, as opposed to individual, action and the relationship between citizens and multiple forms of 
organizing. Likewise, in his chapter on Hong Kong, Maurizio Marinelli stresses the importance of 'markets as spaces of social inclusion and testing grounds for collective experiences of public spaces, and in some cases, practices of democratization' (this volume).

c. Changing people, who then change their cities

Instead of promoting the city for the people from a top-down perspective, a more sensible way of city-building is empowering people and supporting their initiatives. There are already existing mechanisms, such as participatory budgeting, that allow people to decide a portion of the municipal or district public budget, which are conducive to empowerment and often generate multiple proposals that can help create a city by and for the people. Even if experience with these tools is still limited in Asian cities as a whole - and notably absent from the present book - they have gained a critical mass in places like Seoul, Korea and Chengdu, China where, in the latter, 40,00o projects decided by people have been funded through participatory budgeting (Cabannes and Ming 2014). Lessons from these initiatives in Asia are consistent with those from cities in other regions of the world (Cabannes and Delgado 2015) and clearly indicate their capacity to expand residents' involvement at the city scale in a short time, generate new ways of producing and managing the city, and lead to significant people-centred changes. Particularly interesting is the shift from public programs that intend to change a given reality to ones that generate a paradigm shift towards a city by and for the people. One testimony brought from a community leader engaged in Guarulhos, São Paulo Region in Brazil highlights this change: 'PB [participatory budgeting] is a way to change people to change their city' (Cabannes and Delgado 2015).

\section{Towards Human Flourishing, Agency and Alternative Urban spaces}

'The common purpose of the city is human flourishing.' (Aristotle, Politics)

'Exercising agency is integral to human flourishing.' (Lacey 2015, 278)

Although often connected with Aristotle's fourth century BCE concept of eudaimonia, the concept of human flourishing is not unique to Western philosophy. In Asia, Confucianism speaks of human flourishing as learning 
to be human' through the continuous 'creative transformation' of the self in 'an ever-expanding network of relationships encompassing the family, community, nation, world and beyond' (Tu 1993, 142). In the interpretations of Aristotle, Tu, and others (Rasmussen 1989; Lacey 2015), human flourishing is about well-being, derived from the capacities to strive, validate one's personal potential, gain self-fulfilment, and cultivate love and friendship, all of which emerge from engagement with others in society. In contrast to 'happiness', which is a state of satisfaction, 'human flourishing' 'conveys the idea of a process, of both a personal project and a goal for humanity' (Triglav Circle 2015). While individual freedoms are critical (Sen 1998; 2005), human flourishing is realized through inclusive engagement with the society, not in isolation from it, and involves obligations to others. Flourishing is thus a 'communal act'; the self is 'never an isolated individual but a centre of relationships' (Tu 1993, 142). This understanding echoes the idea that the right to the city is a collective, rather than individual, right (Harvey 2003).

Two more aspects of human flourishing are important with regard to the collection of urban research brought together here. First, it provides a much broader, holistic concept of the human condition than the more common formulations that presume human motivations to be wholly economic and material. Defining human flourishing as a fundamental human right to the 'full development of intellectual, physical and spiritual potentials in the context of wider communities', Friedmann $(2000,466)$ establishes it as the central idea of an alternative development meant to counter the hegemony of the prevailing neoliberal world system that diverts human energies to global accumulation. Second, as the actualization of human potential, human flourishing directs attention to human agency. Rather than something that can be defined by a universal set of criteria, human flourishing is a process experienced differently by each person-even as it is simultaneously a collaborative expression of people's capabilities and aspirations for 'another city' (Lacey 2015).

As previously noted, one of the important theoretical lessons of this book is that the appropriation of spaces for de-commodified, alternative visions of urban life is not permanent. The sharing of space is an opportunity to build collective actions and initiate discussions on collaborative management of a place. In practice, these processes may be far from ideal and may be subjected to local forms of power imbalances. The reform and opening of spaces for public use does not guarantee unlimited stability of spatial accessibility, as societies evolve and developmental trajectories may sustain materialist ideologies (Padawangi 2014). However, this is the process through which 
cities by and for the people continue to evolve, with the appreciation that citizens, individually and collectively, are active agents of change, and through which cities are re-established as theatres of social action.

Most of these case studies give an account of a city by the people through insurgent actions, resistance, and other affirmative actions, and very few disseminate outward at the city level, or expand upscale. Moreover, at least two of the cases in this volume (Kampung Pulo in Jakarta and Pom Mahakan in Bangkok) have been evicted or partly demolished while this book was in the process of publication. Nevertheless, the grounded and limited experience of a particular community can have an impact on the city as a whole. Because Ahmedabad's marketplace connects with the whole city, knowledge of the experiences of street traders in Bhadra Plaza is extended throughout the city as a social, cultural, and political entity. Singapore's Blues 77 band meets in specific clubs, but gatherings include fans and musicians from throughout the city. 'Theatre Everywhere' in Hong Kong and Bangkok's network of urban farmers bring people from different and loosely connected communities together at the metropolitan level. Furthermore, through social mobilisations alternative housing improvements in maintaining settlements in various cities in Asia have expanded, not just in Bang Bua Canal (Gerbeaud, this volume), but also in other cities in Thailand and neighbouring countries. We argue that these convivial spaces, albeit being the sites of continuous struggles and embedded with specific limitations that include local hierarchies and contradictions, are places that actively demonstrate the possibility of alternative ways to produce urban spaces. These alternative urban spaces are tangible resistance towards the capitalist production of urban spaces that continues to encroach upon various neighbourhoods, but the sustenance of alternative urban spaces that are socially constructed by the people of the city also indicates the possibility for social imaginations to work towards cities by and for the people.

\section{Works Cited}

Bandura, Albert. 'Self-Efficacy Mechanism in Human Agency'. American Psychologist 37, no. 2 (1982): 122-147. doi/10.1037/0oo3-066x.37.2.122.

---. 2000. 'Exercise of Human Agency Through Collective Efficacy'. Current Directions in Psychological Science 9(3): 75-78. doi:10.1111/1467-8721.00064.

---. 2006. 'Toward a Psychology of Human Agency'. Perspectives on Psychological Science 1(2): 164-180. doi:10.1111/j.1745-6916.2006.00011.x. 
Battilana, Julie. 2006. 'Agency and Institutions: The Enabling Role of Individuals' Social Position'. Organization 13(5): 653-676. doi:10.1177/1350508406067008.

Bourdieu, Pierre. 1998. Contre-Feux. Paris: Liber-Raisons d'agir.

Brenner, Neil, Peter Marcuse, and Margit Mayer. 2012. Cities for People, Not for Profit. London: Routledge.

Cabannes, Yves and Zhuang Ming. 2014. 'Participatory Budgeting at Scale and Bridging the Rural-Urban Divide in Chengdu'. Environment and Urbanization 26(1): 257-275. doi:10.1177/0956247813509146.

Cabannes, Yves and Cecilia Delgado. 2015. Participatory Budgeting, Dossier $N^{o}$ 1. Another City Is Possible! Alternatives to the City as a Commodity. Lisbon: Creative Commons.

Castells, Manuel. 1996. The Rise of the Network Society. Malden, MA: Blackwell. Castells, Manuel. 1998. The Power of Identity. Malden, MA: Blackwell.

Chandler, David. 2013. "Human-Centred" Development? Rethinking "Freedom" And “Agency” In Discourses of International Development'. Millennium:Journal of International Studies 42(1): 3-23. doi:10.1177/0305829813492184.

Chang, Tou and Shirlena Huang. 2008. 'Geographies of Everywhere and Nowhere: Place-(Un)Making in a World City'. International Development Planning Review 30(3): 227-247. doi:10.3828/idpr.30.3.3.

Daniere, Amrita and Mike Douglass. 2008. The Politics of Civic Space in Asia. London: Routledge.

EIU (Economist Intelligence Unit). 2012. Benchmarking Global City Competitiveness. London: Economist Intelligence Unit, Inc.

Friedmann, John. 1962. 'The City in History'. The Town Planning Review 33(1): 73-80. ---. 1987. Planning in the Public Domain. Princeton, N.J.: Princeton University Press. ---. 1992. Empowerment. Oxford: Blackwell.

---. 2000. 'The Good City: In Defense of Utopian Thinking'. International Journal of Urban and Regional Research 24(2): 460-472. doi:10.1111/1468-2427.00258.

Häkli, Jouni and Kirsi Pauliina Kallio. 2013. 'Subject, Action and Polis: Theorizing Political Agency'. Progress in Human Geography 38(2): 181-200. doi:10.1177/0309132512473869.

Harvey, David. 2003. 'The Right to the City'. International Journal of Urban and Regional Research 27(4): 939-941.

Jokinen, Eeva. 2016. 'Precarious Everyday Agency'. European Journal of Cultural Studies 19(1): 85-99. doi:10.1177/1367549415585548.

Kirby, Andrew. 2002. 'Do Cities Have a Purpose?'. Cities 19(6): 371-372. doi:10.1016/ s0264-2751(02)00067-7.

Lacey, Hugh. 2015. 'Food and Agricultural Systems for the Future: Science, Emancipation and Human Flourishing'. Journal of Critical Realism 14(3): 272-286. doi:10. 1179/1572513815y.0000000002. 
Lefebvre, Henri. 1991. The Production of Space. Oxford, UK: Blackwell.

Lefebvre, Henri. 1996. Writings on Cities. Oxford, UK: Blackwell.

Mumford, Lewis. 1961. The City in History. New York: Harcourt Brace Jovanovich.

Padawangi, Rita, Peter Marolt, and Mike Douglass. 2014. 'Introduction to the Special Issue: Insurgencies, Social Media and the Public City in Asia'. International Development Planning Review 36(1): 3-13. doi:10.3828/idpr.2014.1.

Padawangi, Rita. 2014. 'Reform, Resistance and Empowerment: Constructing the Public City from the Grassroots in Jakarta, Indonesia'. International Development Planning Review 36(1): 33-50. doi:10.3828/idpr.2014.3.

Peattie, Lisa. 1998. 'Convivial Cities'. In Cities for Citizens: Planning and the Rise of Civil Society in a Global Age, 247-253. Mike Douglass and John Friedmann, 1st ed. London: John Wiley.

Rasmussen, Douglas. 1989. 'Individual Rights and Human Flourishing'. Public Affairs Quarterly 3(1): 89-103.

Sandercock, Leonie. 1997. Towards Cosmopolis. Chichester, England:J. Wiley.

Sandercock, Leonie and Peter Lyssiotis. 2003. Cosmopolis II. London: Continuum. Sen, Amartya. 1998. 'The Possibility of Social Choice'. Nobel Lecture, December 8, 1998. https://www.nobelprize.org/nobel_prizes/economic-sciences/laureates/1998/sen-lecture.pdf

---. 1999. Development as Freedom. New York: Knopf.

---. 2005. 'Human Rights and Capabilities'. Journal of Human Development 6 (2): 151-166.

Shin, Hyun Bang. 2015. 'Economic Transition and Speculative Urbanisation in China: Gentrification Versus Dispossession'. Urban Studies 53(3): 471-489. doi:10.1177/0042098015597111.

Triglav Circle. 2016. 'Human Flourishing and Social Justice'. Triglav Circle. http:// www.triglavcircleonline.org/2005/12/human-flourishing-and-social-justice.

Tu, Wei Ming. 1993. 'Our Religions'. In the Seven World Religions Introduced, 139-227. Arvind Sharma, 1st ed. San Francisco: Harper.

UNESCAP. 2012. The State of Asian Cities 2010/11. Bangkok: UNESCAP.

Van Voorst, Roanne and Rita Padawangi. 2015. 'Floods and Forced Evictions in Jakarta'. New Mandala. http://asiapacific.anu.edu.au/newmandala/2015/08/21/ floods-and-forced-evictions-in-jakarta.

Young, Iris. 2004. 'Five Faces of Oppression'. In Oppression, Privilege, and Resistance, 37-63. Lisa Heldke and Peg O'Connor (eds.). New York: McGraw-Hill. 


\section{About the authors}

Yves Cabannes is an Urban Planner and activist, Emeritus Professor of Development Planning and former Chair of Development Planning [2006-2015] at Bartlett Development Planning Unit (DPU), University College London, UK. His previous appointments include visiting post-graduate scholar positions in European and Latin American universities and a lectureship in Urban Planning, Harvard University Graduate School of Design (2004-2006). In 1997-2003, he was the regional Coordinator of the UN Habitat/UNDP Urban Management Program for Latin America and the Caribbean. He has particular experience and interest in participatory budgeting, urban agriculture \& food sovereignty, collective and communal forms of land tenure, local currencies, participatory planning, municipal public policies, low cost housing, community-based micro credit systems and appropriate technologies for local development. He is an advocate on development and rights issues and was the convener for the UN Advisory Group on Forced Evictions (2004-2010).

Mike Douglass is Emeritus Professor and former Chair of the Department of Urban and Regional Planning at the University of Hawai'i where he was also Director of the Globalization Research Center. He holds a Ph.D. in Urban Planning from UCLA. From 2012-2018 he was Professor and Leader of the Asian Urbanisms Cluster in the Asian Research Institute and also Professor in the LKY School of Public Policy, National University of Singapore. He has served as consultant and staff member of international agencies and governments, including the United Nations. His recent books are: The Rise of Progressive Cities East and West; Crossing Borders - Governing Environmental Disasters in a Global Urban Age in Asia and the Pacific; and Disaster Governance in Urbanising Asia.

Rita Padawangi is Senior Lecturer at the Singapore University of Social Sciences. Previously, she was Senior Research Fellow of the Asian Urbanisms cluster at the Asia Research Institute (ARI), National University of Singapore (NUS). She received her PhD in sociology from Loyola University Chicago, where she was also a Fulbright Scholar for her master of arts studies. She holds a bachelor of architecture degree from the Parahyangan Catholic University. Her research interests include the sociology of architecture and participatory urban development. She is a member of the collaborative Southeast Asia Neighbourhoods Network (SEANNET), a four-year initiative for urban studies research, teaching and dissemination through the perspective of the neighbourhood, funded by the Henry Luce Foundation through the International Institute for Asian Studies (IIAS). 